\title{
More than a Method? Organisational Ethnography as a Way of Imagining the Social ${ }^{1}$
}

The authors - two anthropologists and an organisational theorist, all organisational ethnographers - discuss their understanding and practices of organisational ethnography as a way of imagining and reflect on how similar this understanding may be for young organisational researchers and students in particular. The discussion leads to the conclusion that organisational ethnography may be regarded as a methodology but that it has a much greater potential when it is reclaiming its roots: to become a mode of doing social science on the meso-level. The discussion is based on an analysis of both historical material and the contemporary learning experiences of teaching organisational ethnography as more than a method to our students.

Keywords: organisational ethnography; anthropology; teaching and learning organisational ethnography, sociological imagination; ethnographic imagination; research methods

Word count: 7,917

\footnotetext{
${ }^{1}$ We would like to thank the anonymous Reviewers and the Editor for their thoughtful comments which helped us to considerably improve this article.
} 
As a science, organizational ethnography needs to be concerned with creating systematic generalizations about "how the world works". It needs to be theoretically informed and informing; it needs to contribute to the broader body of knowledge which constitutes organization and management studies. It enables theoretical, rather than empirical, generalizations to be made. (Watson 2011, 209)

\section{Introduction}

Heidi Dahles, Heather Höpfl and Juliette Koning (2014) note that conventional thinking views organisational ethnography basically as a method. This text aims at presenting organisational ethnography as something more: a way of learning sociological and organisational imagination. Sociological imagination is a capability enabling the individual to rise above her or his everyday social context, making it possible to acquire the distance necessary for critical reflection and change (Mills 1959). Organisational imagination is its special case, reflexively focusing on processes of organising (Kostera 1996; Mir and Mir 2002).

We argue that ethnography has its origins as a research method but from its very beginning had a particularly high potential to support the development of sociological imagination. Subsequently,

it has evolved beyond being solely a method and has become a perspective in organisation studies (OS), which enables learning and actively using sociological and organisational imagination.

Imagination is vital for any type of organisational activity that is aimed beyond the status quo for renewal and change (Morgan 1993), for a establishing a balance between continuity and change (Watson 2009) and for purposeful sense-making (Weick 2001).

Our contribution consists of showing that organisational ethnography (OE) as an approach to both research and organising has a value for emancipatory education, based on the idea that education should help an understanding the role and the acting for creation of a just society (Freire 1970; Giroux 2004; McLaren and Giroux 1989; McLaren 2003; Nouri and Sajjadi 2014) 
by developing imagination (Mills 1959). It helps to critically reflect on the broader social context and may have consequences for both radical change and resistance. To illustrate this argument, we use examples of both historical and contemporary ethnographic research projects.

Our argument evolves as follows. Firstly, we reflect on the use of ethnography as a method only. Secondly, we discuss the role of imagination for emancipatory understanding the social in organising. Subsequently, we illustrate the foundational origins of OS and ethnography by explaining the ethnographic understanding of the anthropologist-sociologist Lloyd Warner (Warner and Low 1947) who epitomises the common origins of organisation studies and anthropology of the organisations, introducing a reflexive and highly imaginative approach to the

field. We then give a very brief overview (given the limitations of space in the paper) of different and similar assumptions about what organisational ethnography was as a research practice (Van Maanen 2011) for organisation studies (OS) and anthropology. Finally, we finish by presenting how organisational ethnography is experienced by current university students and academics and the similarities between their understanding of their methodological approach and practices and that of the founders of the discipline, especially Lloyd Warner. We propose that students' engagement with organisational ethnography suggests the potential for the reclaiming of a tradition within the discipline that enables the bridging a long and non-productive time of divergences that created the understanding of organisational ethnography as only a menu of tools, methods or techniques. To show why and how this is significant, we will now discuss ethnography and the importance of emancipatory imagination for organising.

\section{Ethnography as a research method}

Socio-cultural anthropologists typically do not view ethnography as merely a method (see, e.g., 
Wolcott 1999; Ingold 2008). While there are numerous publications explaining the principles of ethnographic methods, it is hard to find anthropologists engaging in such writing, unless they are transdisciplinary researchers, such as H. Russell Bernard (2011). While embracing the view that ethnography is an approach to research, anthropological texts on methodology often reflect on the problems and issues of being in the field, such as for instance, the intimate relations with research participants (Kulick and Willson 1995; Markowitz and Ashkenazi 1999), emotions (Powdermaker 1967), or the researcher's identity and self consciousness (Nash et al. 1972).

In OS, as represented in management and organisation research methods handbooks, however, it is quite a common view that ethnography is (only) a method (for discussion, see Dahles et al. 2014). Authors refer to ethnography as a method embedded in a particular conception of organisations, those of cultures, an "obvious method for understanding work organisations as cultural entities" (Bryman and Bell 2007, 441). Others prefer to emphasise the power of ethnography as a method to understand the microscopic dimension of organising, that "make it possible to explore little-known phenomena without having to establish a rigid conceptual framework" (Charreire and Durieux 2001, 61). Randy Hodson defines the ethnographic study simply as "methods of observation" $(2004,12)$. There are even authors who define organisational ethnography as a part of other methods, an "in depth case study analysis" (Royer and Zarlowski 2012, 114) or as a "methodological assumption" (Collis and Hussey 2003, 60). Research Methods Handbooks, because of their wide circulation and clear and pervasive style of writing, have considerable potential for shaping the dominant perception of ethnography.

Whereas the vast bulk of publications within OS dealing with ethnography emphasises method over perspective, there are also other, more holistic views. Dvora Yanow and Karin Geuijen (2009) emphasise ethnography as also being a style of writing and a sensibility. A number of 
organisational scholars, such as Barbara Czarniawska (Czarniawska-Joerges 1992; 1993;

Czarniawska 2014), Monika Kostera (2007), John Van Maanen (1988) and Tony Watson (2001), adopt a much broader approach to ethnographic research in organisations, which is typical of anthropologists. We agree with this latter perspective. Ethnographies do not just observe and describe but focus on the "cultural picturing of how it is to be someone else," as John Van Maanen succinctly stated (1998, xx). Furthermore, critically oriented organizational ethnography strives at broadening consciousness about important social issues, thus enabling active participation in the creation of a more just society (Alevesson and Deetz 200; Sykes and Treleaven 2009). In this text, we intend to reclaim and elaborate on this important yet currently often neglected characteristic.

\section{The role of imagination for understanding the social in organising}

C. Wright Mills coined the term sociological imagination in 1959, understood as an ability that makes it possible for the individual to reflexively acquire distance for her or his everyday world. Reflexivity goes beyond taken-for-granted ways of sense making (Cunliffe 2004), and as part of imaginative praxis, it enables the person to envisage other ways of doing things, to look beyond the level of everyday context seen as a necessity and given, such as the constraints of social class, family and work. According to Mills (1959), the sociological imagination makes connections between the larger picture and the local situation, the here and now and the historical - hence the importance of learning about history. Evan Willis (1993) proposed that sociological imagination consists of four types of factors: historical, cultural, structural and critical. These factors enable perception of the distinction between personal troubles, which are part of her or his immediate milieus, and public issues, which transcend the individual's local situation (Mills 1959). Seen 
from such a perspective, individual constraints become part of a broader context; problems which appeared insoluble can now be solved, albeit in a systemic way, and often with the extensive use of organisations and organising. Hence, the notion of organisational imagination (Kostera 1996; Mir and Mir 2002) is a derivative of sociological imagination, a type of a dialectical bridge between reflection, practice, and back to reflection again (Kostera 1996), a state of mind enabling organisational participants, researchers and consultants to envisage organisations as controllable and find suitable means of controlling them (Mir and Mir 2002).

The sociological and organisational imagination link individuals and groups, roles and societies, past and present. They reveal the differences and similarities between the collective and the individual and focus attention on one dimension or the other. The sociological and organisational imagination are abilities with some individual, cultural, sociological and political consequences, which, even in a situation of the current systemic crisis, which Zygmunt Bauman (2012) refers to as the interregnum, can offer hope for radical renewal and systemic change. Such change may be carried out on an organisational level without the necessity to wait for vast societal shifts, and organisation and management studies may help here (Kostera 2014). Gareth Morgan (1993) argues that imagination makes it possible for people to deal constructively with organisational change. Karl Weick (2001) considered imagination crucial for sense making in organisations, and organising as a process continuously structured by sense making.

A way of looking at the world that encompasses imagination is important. Paul Willis has been working on how to acquire and use it with regard to the social. Inspired by Mills he utilises "imagination" and not, for example, "sensibility" or "analysis", terms that are less surprisingly collocated with ethnography because the latter terms refer to creativity and exceeding the everyday. Willis studied ethnographically "lads", children of working-class parents, and shows 
how their class defines their life choices, limiting their educational aspirations, and how their cultural consciousness within the constraints of the broad context reproduces the existing social structure (Willis 1981). Willis reports the symbolic resistance of the "lads" against dominant values, which, as a result, contribute to the reproduction of the structure they challenge. He argues that only fieldwork and the sharing of results with social actors in the field can truly transcend the mechanisms of the perpetuation of social structure and privilege and thus produce a type of co-authored emancipation with the active involvement of researchers in the field. In his other seminal book, The Ethnographic Imagination, Willis (2000) further explores this characteristic of ethnography. He defines ethnography as an approach to the social and cultural that enables the understanding of experience and creativity. It engages the senses, the presence of researchers in the field, and intellectual faculties. Thus, ethnography reaches beyond practice and theorising: it involves that which is the most elusive and yet most human and usually is disregarded by sciences and research methods, including those of the social variety consciousness. Willis makes a strong argument for the irreducibility of experience in social and cultural practice and shows how ethnography is able to tackle the experience, if not itself reduced to just a method. Ethnography is, thanks to its imaginative aspect, an art, not a technique and is a dynamic dialectic relationship between practice and theorising. Potentially, it can help to turn everyday life into a creative experience for the researcher as well as for the actors in the field. Is there a possibility to learn imaginative ethnography? Paul Willis (1999) identifies the socially reproductive links between the cultural role of commodities and the aspirations of young working class people, which formal education perpetuates but which a radical pedagogic policy, developing expressive labour power, might help to transcend. The imaginative ethnographic project can thus be seen holistically as an emancipatory endeavour that simultaneously involves 
seeing and understanding, problematising, practicing and learning. Adopting sociological imagination makes it possible, as Tony Watson notes, to engage critically with what can be called the "'bigger' questions of human existence" (Watson 2009, 873), to challenge what is taken for granted and to advance knowledge generally. A balance between change and continuity can be achieved with such scientific work, enabling theorising as well as carrying the results beyond the limitations of the academy.

We would now like to show how the above issues (albeit in different proportions) are present throughout the development of $\mathrm{OE}$ from early anthropological inspirations via further advances to contemporary uses.

\section{Lloyd Warner and the first organisational ethnography}

Our reflection is rooted in the history of anthropology and management and organisation studies. This inscribes our text within a broader stream of historical explorations of management ideas. However, the article is not a full-fledged historical study; we do not take a precise historiographic standpoint, and our use of archival data is very limited. However, we identify with the view presented by some management historians that some take for granted popularised concepts that need to be traced back to their origins to refresh them and prevent them from degradation and simplification (Down 2001; Jacques 2006; Down 2012). As our discussion here shows, illustrated by the historical vignette of $\mathrm{W}$. Lloyd Warner, organisational ethnography has a rich foundation from which we can draw inspiration and learning. By reflecting on the foundation of organisational ethnography, we pretend to place ourselves in a moment less concerned with disciplinary boundaries and less influenced by institutionalised academic professionalism, similar 
to the situation we encourage for our business research students when imagining the social. In the consecutive sections when we explain the OS and anthropology divergences and convergences, we continue a historically rooted reflection on the use of ethnography. We believe that by presenting a history of organisational ethnography, we can connect "to present-day issues in a manner that may lead one to look at these issues differently" (Jacques 2006, 43). Holistic ethnography inspires researchers to look beyond the boundaries of an organisation. This corresponds with the observation made by some organisation theorists that the discipline's research subject, an organisation, is fading, and organisational fields are of growing importance (Davis and Marquis 2005). In such circumstances, ethnography and organisational imagination is even more important than in previous phases of organisational studies history. If the predictions that a "general 'theory of fields' will eventually fill the space held by organisation theory" (Davis and Marquis 2005, 340) become a reality, ethnography as a way of imagining organisation rather than another mere method of studying organisations could become a relevant contribution.

Contemporary organisational scholars show a growing interest in Lloyd Warner's work (Baba 2009; Luthans et al. 2013; Van Maanen 2013). Marietta Baba (2009) suggests that organisational ethnographers should study organisations within the broader social context and not be trapped “inside organisations" (Gellner and Hirsch 2001). Warner's approach to studying organisations is one of the earliest instances of this broader approach to learning about organisations; the case serves to provide an example of how sociological imagination operates. In this section, we develop Lloyd Warner's story as an introductory historical vignette that illustrates an early organisational ethnography in its holistic form.

Here, we mainly discuss Warner's involvement in Elton Mayo's Hawthorne Research and the Yankee City project he led by himself. In both examples, not only Warner's holistic approach to 
research is visible but also an application of sociological and organisational imagination can be seen as well.

Elton Mayo recalls how "a representative of the Harvard Department of Anthropology [Lloyd Warner] had called attention to the logical insufficiency of a merely psychological study of the individuals in a department" (Mayo 1933, 111). Instead of being reluctant, protective of his own academic territory or, in Bate's words, “ratings merchants" (1997, 1151), Warner's suggestion led Mayo to the idea that "an anthropologist skilled in the use of field techniques was necessary" (Mayo 1933, 138) to work on the project. To realise the idea, Mayo invited Warner to join the research team.

Warner had a deep impact on the Hawthorne project, as he designed a research procedure that combined observations and interviews and introduced Radcliffe-Brown's anthropological structural theory as a theoretical framework (Gillespie 1993). Another of his important contributions to the project was highlighting the importance of the meso-level as a means to imagining the social. From the beginning, Warner's idea was to analyse the relations of workers in a broader social context that exceeded the boundaries of the factory. According to Warner, anthropological methods were best suited to study whole groups. After working with Elton Mayo within the frames of the Hawthorne project, he picked Newburyport (in the final publication, it is called Yankee City), a small town 40 miles from Boston.

One out of five volumes of the Yankee City series was devoted to the analysis of shoe factories (Warner and Low 1947) and can be considered one of the earliest examples of organisational ethnography as a type of a sociological imaginative practice. Some authors have neglected Warner's work as foundational to the discipline (see Gill and Johnson 2002). However, Van 
Maanen (2013) suggests that the origin of organisational ethnography was precisely in the Yankee City series, not in Hawthorne studies.

Warner [...] went on after his brief stint at Hawthorne to study organisations, occupations, and institutions in a far broader and more thoughtful fashion than was the case at Hawthorne, writing a series of dazzling community ethnographies of Yankee City (Newburyport, Massachusetts) in the period of emerging unionization in the USA. It seems then that if we need a primogenitor for organizational ethnography, W. Lloyd Warner is the one and Yankee City is the birthplace, not Hawthorne (Van Maanen 2013, 107).

Although Warner's flagship project in Newburyport could be seen as an even more important contribution to the development of organisational ethnography than his involvement in the Hawthorne project, the Yankee City study is rarely considered neither an organisational ethnography nor a study of organisational behaviour, probably because of its focus on the entire community of Newburyport and not on a single organisation. As a result, the main findings deriving from Warner's study have been labelled "sociological" rather than "organisational" and thus are seen as a contribution to social class theory (rather than to organisation theory). A similar fate met what Morey and Luthans (2013 [1987]) label yet another "classical example of an organisational ethnography," or Whyte's Human Relations in the Restaurant Industry, published one year after Warner's work (Whyte 1948). Although both Warner and Whyte, who worked together at the Committee on Human Relations in Industry in Chicago, were truly interdisciplinary researchers (Whyte's university degree was in sociology, not in anthropology), their work was usually not considered as part of the foundational roots of the studies of organisations (except by recent authors such as Czarniawska-Joerges 1992 and Kostera 2007).

Some other indices of the divergences of the practice of organisational ethnography by anthropology and organisations studies, which we address in the next section, can be found in these first organisational ethnographies. Most of the publications that emerged from Warner's Yankee City were devoted not only to community problems but also to a category of problems 
other than strictly mainstream organisational behaviour. Warner and his team studied, among others, class and social structure, ethnic relations, formal and informal associations, symbolic behaviour, economic behaviour, church and school and issues of ownership (especially houses). They covered intertwining historical, cultural, structural and critical aspects of organising, all of them that could be considered, following Willis (1993), elements of imagining the social. Strictly organisational elements in Warner's studies were dispersed through publications in which Warner analysed both commercial and non-commercial organisations. It was precisely at this time when the first divergence happened. Barbara Czarniawska-Joerges (1992) notes that anthropology and organisation studies, having merged in the Hawthorne Studies, of which Warner was an active research member, began to separate after the 1930s.

\section{At the crossroads: Moving apart}

Two factors that led to the separation were a demand for a "rigorous" method to study organisations and, related to that, the dominance of positivistically inclined management research. Morey and Luthans (2013 [1987]) suggest that one of the reasons for taking different routes was that both anthropology and ethnographic research were regarded as less important than psychology (and to a lesser extent, sociology) in their contributions to the origins of organisational studies. This occurred because management and organisational behaviour became defensive about academic respectability: "good research became equated with quantitative research" (Morey and Luthans 2013, 87).

However, at the foundational origins of the discipline, as we will explain later, the opposite rhetoric was considered valid: the team led by Elton Mayo (1933) based the credibility of their research on the support of observations from qualitative anthropologists when he discovered that psychological and psychiatric approaches made the progress at Hawthorne inconclusive. Dvora 
Yanow, Sierk Ybema, and Merlijn van Hulst (2012) insist that this study was based on the ethnographic ethos of "being there," a holistic depiction of organisational life, including its "nonrational" aspects, such as politics, customs and their dysfunctional consequences.

Morey and Luthans (2013) propose that a more sociological approach to participant observation for some of Warner's followers after the foundation of the Committee of Human Relations in Industry in Chicago and the later re-introduction of a distinctive anthropological approach to the study of organisations as represented by William Foote Whyte (1948) within this same group created the first crossroads between organisation studies and anthropology. Ann Jordan (2003) suggests that the economic and financial depression and the end of the Hawthorne studies during the 1930s produced an absence of anthropologists in organisational settings until World War II. Ethnography was considered at that time a distinctive anthropologic methodology, a "trademark of cultural anthropology” (Schwartzman 1993, 1). Gradually, a rhetoric of interpreting Warner's work as a pure methodological contribution to the Hawthorne studies gained consensus. This resonates with the later interpretation of ethnography in management and organisational research purely as an alternative methodology used when other methods fail but rings as a misinterpretation of Mayo's call for Warner's contribution. As Morey and Luthans (2013 [1987]) note, Warner was invited to work fully as an anthropologist, not just to apply ethnographic methods at Hawthorne. In fact, the recognition of a distinct informal organisation was not only the result of Warner's interviews but of his capacity to imagine the social world of Hawthorne and the Bank Wiring Room. It was the capacity to observe, the social sensibility of imagining when ethnographing (Tota 2004), with what Beth Bechky describes as "anthropological sensibility” (Bechky 2013, 97), or, in Barbara Czarniawska-Joerges' (1992, 29) words, an "anthropological frame of mind" that made it possible for Warner to understand that the informal 
organisation at Hawthorne "also included their immediate supervisors" (Morey and Luthans 2013 [1987], 84). Warner was reported to be obsessed with "keep[ing] a continuous record of all activity that was observable" (ibid.), an obsession that was much more than simply the adoption of a particular methodology. Susan Wright highlights that Warner's main contribution was not the application of a particular technique but the capacity to observe (Wright 2013).

The idea was to embrace interdisciplinarity and be receptive to what was observed, to imagine the social out of the data and to derive the whole from the parts in an abstract way. According to Morey and Luthans (2013[1987]), his methodological contributions were fewer than his theoretical contributions; in fact, Warner came from a traditional open approach of concentrating on ethnos, people. The people observed and described by Warner and his circle of anthropologists were not pre-conceived as "organised"; only after prolonged contact were the researchers willing to draw conclusions as to whether an organisation existed among them at all. Anthropologists such as Bronisław Malinowski, Alfred Radcliffe-Brown, Ambrose EvansPritchard (or even, much later, Clifford Geertz), considered people to be temporarily grouped, held together at the moment of observation.

For Radcliffe-Brown (1931), a social organisation was an attribute of a group of people, not the group itself. To be a group was not necessarily the same as being organised as a group. First, social anthropologists refer to people by the name of a tribe (Azande, Nuer, Sanusi; EvansPritchard 1937; 1940; 1949), a practice (Argonauts; Malinowski 1922), a place (natives), or generically as communities (Evans-Pritchard 1951). This understanding of ethnography as an interdisciplinary way of observing but also of imagining and narrating people was also reflected in the research approach adopted by some of Warner's followers such as Eliot Chapple, Conrad Arensberg and William Foote Whyte in the 1940s. 
The attention to the wider community and the necessity of being interdisciplinary, in the words of Ann Jordan, both quantitatively and qualitatively pending on the observation rather than a predefined hypothesis (Jordan 2003) was likely the second cause of the diversion or the split between the disciplines, in particular when the interdisciplinary emphasis was later reinforced by Whyte and others in Chicago. Wright suggests that another reason was the traditional lack of predefined hypotheses and research problems of the ethnography conducted by anthropologists (Wright 2013). The opposite characterised most of the following organisational research from organisational behaviour studies during the 1960s and the 1970s that ascribed to the precepts of natural sciences methodology, assuming "that distinctive objects exist and that the researcher's task is to discover their variable attributes to formulate principles determining their formation" (Czarniawska 2008, 7). In contrast, by the 1960s, the anthropologists studying organisations moved to even more open and less predictable understandings of organising, such as cultural ecology (Steward 1955), and started questioning the ethical dimension of conducting ethnography sponsored by organisations, a debate invisible in organisational behaviour, which leads us to the issue of convergence and separation between anthropology and OS.

\section{Convergences in the context of the separation}

For Daniel Neyland (2008), the distinction between anthropology and organisation studies has become so clear that it is now possible to refer to the ethnography practiced by organisational scholars as essentially different from the ethnography practiced by anthropologists. Some researchers show that these two groups also differ enormously in the research questions they ask. Dvora Yanow commented on it using an example of one of the anthropological edited volumes presenting organisational ethnographies: "chapters in Gellner and Hirsch (2001) [...], left me ill at ease, wondering why the volume's anthropology-trained authors appeared surprised by the 
problematics of organisational forms and structures, hierarchies and bureaucratic politics, turf wars and control, and other organisational studies topics that they 'discovered' and discussed" (Yanow 2009, 190).

In 1997, Bate warned that "organisation studies lost touch with the essential qualities of anthropology" (Bate 1997, 1148). For anthropologists, organisational ethnography became instead a subfield of their own discipline, permeated by the same dilemmas and theoretical and methodological challenges as anthropology. Many organisational ethnographers pursue studies inspired by ethnographic methods, perhaps aiming at an understanding of culture (Bryman and Bell 2007), enabling the study of social interactions without a structuration of context (Charreire and Durieux 2001) or focusing on the actual organisation as a case (Royer and Zarlowski 2012). However, in a parallel process, there is a strong convergence. In the mid-1990s, organisational ethnography as a methodology took root in organisation studies at the same time when cultural anthropology was experiencing what was later called the "narrative turn", which appeared in organisation studies slightly later (Czarniawska 2004). After what seemed to be a moment of separation, both disciplines have, with the narrative turn, been diverging and converging in their practices and conceptions of organisational ethnography. Jordan suggests that a first tendency towards converging occurred by the 1980 s, when management journals started to accept contributions from anthropology, especially from researchers discussing methodological issues (Jordan 2003). This resonates again with the suggestion in the narrations of the early history of the discipline and the interpretation that attributes to Mayo the search for methodological support from "other" social sciences.

Thus, today, there are some possibilities, albeit not obvious, for meetings and convergences. For contemporary anthropologists, ethnography has become a style of imagining based on thick 
descriptions of people's lives (Ingold 2008). This view is shared by some OS researchers: ethnography is seen as a paradigm, a way of understanding research (Easterby-Smith et al. 2002), a mindset of the researcher (Czarniawska-Joerges 1992; Kostera 2007), and an approach to research (Fineman 2013). For some, OS ethnography is more "a label of choice or researchers working in professional and applied fields, who have discovered and adapted ethnographic methods to suit their own purposes" (Bryman and Bell 2007, 441, our emphasis) or even "a research strategy that focus upon describing and interpreting the social world through first-hand study" (Saunders et al. 2007, 597, our emphasis) or a "research tradition which shares some overlap with phenomenological traditions, but is quite distinct in its own right" (Lee and Lings 2008, 62, our emphasis). For John Van Maanen, ethnography is both "a methodological approach to and an analytic perspective on social research" (Van Maanen 2011, 218). Contemporary anthropologists studying business and management topics still consider ethnography to be an approach, a "view" and "analysis" (Ho 2009). However, Dvora Yanow, Sierk Ybema, and Merlijn van Hulst (2012) conceive organisational ethnography as a way of performing research that is particularly sensitive to actors, contexts and "hidden" dimensions of organisations and cultures. Furthermore, Halleh Ghorashi and Harry Wels (2009) raise a voice for an engaged and emancipating ethnography of organisations, by bringing an understanding of the everyday organisational life of people at lower levels of organisational hierarchies.

Despite these convergences, the academic research environment in which organisational and anthropological ethnographers have developed their ethnographic work is still the perfect context to stimulate a division. Neyland comments that management research often operates with particular expectations regarding the number of publications to be produced. Ethnographic 
analyses generally operate at a far slower pace than alternative management research methodologies.

In business schools, the utility of ethnography thus requires some demonstrative effort on the part of the ethnographer in convincing colleagues, head of departments and so on of some specific form of value (Neyland 2008, 8).

However, Bate notes (ten years before Neyland):

One full-length published ethnography every 3 years (which is quite good going) is not likely to satisfy "ratings" merchants or one's head school; and sabbaticals that used to permit a full-time period in the field are not longer available to the majority. In the present climate, Rule 1 for aspiring organization researchers surely has to be: keep away from organizations; fieldwork takes too long! (Bate 1997, 1151).

This is the view opposite to that held by many departments of anthropology, where short-term and opportunistic "just in time" research is often considered as an indication of non-scientific and poor quality work. Hugo Gaggiotti notices that, probably led by these concerns, some ethnographers prefer to clarify, when presenting themselves and their ethnographic work in scientific meetings, that they do not work in business schools but in faculties of universities (Gaggiotti 2011). For this superficiality and excessive speed, organisational ethnography often encounters critique from cultural anthropologists (Wright 1994). By and large, organisational ethnographers accept the crux of this criticism, which is that the time-span of research in organisations is usually much shorter than that of cultural anthropology and that there is significantly less actual involvement. Nevertheless, they also hold that the subject matter of their research does not require such a deep immersion but rather relates to its selected aspects or areas (e.g., Rosen 1991; Erlingsdóttir 1999). Sometimes, these explanations are met with understanding and even respect from anthropologists, which one of us, as an organisation theorist, often experiences when she talks with researchers from anthropology departments. These differences in engagement are thus both another crossroads and a sign of divergence as yet another meeting point and indication of convergence in the instances when anthropology actually accepts the 
reasons given by OS and treats it as a partner. The potential for closer collaboration and convergence and, ultimately, the reclaiming of a common fruitful tradition, lies, we believe, in educational praxis.

Reflecting on OE's historical path is a refreshing exercise that prevents ethnography from being an element taken for granted in the academic landscape. Indeed, our exploration was aimed at highlighting that the use of OE in OS and anthropology is and probably will be different because of differences in types of formulation by these two disciplines' research questions and the different institutional framework in which they operate. However, because of common roots, both disciplines can overcome the limitations of departmentalisation and continue an enriching dialog about organisational ethnography as something more than a method, as both disciplines use ethnography as a vehicle for creating and facilitating change in the learning experience.

\section{Learning to imagine the social ethnographically}

This section of our article is dedicated to show how organisational ethnography is practiced as a way of engaging sociological and organisational imagination. Based on 18 years of experience of teaching organisational ethnography in several countries, at several universities in graduate, postgraduate, doctoral, and MBA programmes, we will present examples of ethnographic projects, approaches and topics, and, finally, some of the implications for how the social is understood by students: young university researchers and practitioners when their approach is ethnographic in nature. The projects were conducted by graduate (during their fifth year of studies) and postgraduate (doctoral and MBA) students. After a theoretical and methodological introduction, they were asked to conduct an ethnographic study in an organised field of their choice and present it in class. All of the projects were conducted in groups (2-5 people) over the course of one semester. No formalised instructions were given to the students; instead, the approach and 
methods were explained by the teacher, and numerous examples were presented in class by the teacher based on her own research as well as by graduates of the course who had completed particularly interesting projects. The teacher offered extensive feedback in class and on a dedicated website to which all of the students had access.

First, we present the projects, using Paul Willis' (2000) notions of ethnographic imagination, as empathic immersion and direct experience of the field. Then, we briefly address the sociological imagination that the students developed by means of Evan Willis' (1993) framework of sociological imagination. We believe that sociological imagination holds an emancipatory potential of the kind the Paul Freire $(1970 ; 1974)$ speaks of, i.e. by gaining insight into social life that enables people to have a broader basis for the making of life choices. Understood this way, sociological imagination shows, by greater consciousness into the lives of ordinary organisational participants, ways out of situations seemingly fixed in which they have no agency. Finally, we link the two types of imagination and address the possibility of the students having acquired organisational imagination during their research.

Following Paul Willis' (2000) call for immersion to acquire understanding, the students were encouraged to find a particular field that interested them. Their choices were interesting in themselves: quite many opted for wider, not as well-defined or limited settings. Only a smaller group of students focused on an inside organisation, but interestingly, in relation to the broader context, their method resonates with what Warner did. Two typical and particularly interesting examples of this type were projects about a political party (Duda et al. 2013), often regarded as a fringe group, with ideas based on conspiracy theories, and an astronautics study group (Karpiuk et al. 2013). In these two projects, the main protagonist of the study was the organisation itself, although the story was spun by highlighting relationships and interactions between people. A 
large group of projects had an organisation as a frame, with some of the participants as the main protagonists. A typical example was a study of bus drivers in Warsaw (Byrska and Kruk 2013), which was carried out in one public transport company from the perspective of the bus driver. Another example was an ethnography of police work (Siewczyk and Skoneczna 2009). The students focused on the employees of a specific police station, but their tales of the field transcended the frames of the organisation and included stories from other places and settings. Like Warner, who discussed through Yankee City other problems than those that were strictly organisational, our students wanted to extend the organisational ethnography settings from the organisation itself despite the original suggestion of deciding on an organisational setting. Many students chose organised professions as their main protagonists. A study of conductors (Pazura and Żelazko 2012) was particularly pertinent, as it traced the fates and career routes of several Polish conductors, working with various organisations from the military to classical orchestras, both those that were famous and less well known. A project on kitchen personnel, and especially the chef, was conducted in one restaurant, but the organisation served only as a background of the tale (Jewasińska et al. 2012). A large number of projects had an organised setting as its main theme, and within it, the organised activities of one or several groups of people. Thus, for example, a study of the Warsaw horse races (Banaszak et al. 2013) depicted the work of the jockeys and some of the employees of the Hippodrome but also followed the activities of the visitors, both regulars and incidentals. A nightclub was similarly presented (Cała et al. 2008) in a study portraying the employees, from managers to bouncers, but primarily showing the setting as a frame organising a certain lifestyle. More recently, there have been a growing number of projects depicting various public spaces as settings for organising activities. For example, a study of a bazaar in Warsaw (Gurgul et al. 2013) showed the bazaar itself as a large organisation with its own problems of (failing) strategy and identity but also as a traditional public space used to 
provide the context for many activities, from trade to games to social encounters. Location-based games (Krasny et al. 2013) were organised for gain and enjoyment by a firm run by young people, but the location itself, Warsaw City, was more than a background in the story; in fact, it emerged as a social actor by its own merits in a similar way to the urban world of Newburyport analysed by Warner.

An overwhelming majority of the research studies were interesting and well done. Only a few did not pass due to not being in-depth enough, being only concerned with superficial issues, or being focused on the pure application and demonstration of theories and models (such as the so-called Schein pyramid). A large number of studies was striking, fascinating and in some way illuminating, not just for the authors themselves but for the other students and for the teacher. The students were quite often empathetic, even if they chose organisations considered to be fringe or even abnormal by the media (for example, Duda et al. 2013) or that were disliked by many of their peers, such as the police (Siewczyk and Skoneczna 2009) or club bouncers (Cała et al. 2008). Many times, the audience claimed that their view of a specific group or organisation changed after a presentation in the sense that they became more sympathetic to or understanding of the community. Many of the authors and of their audiences also expressed a stronger interest in the social sphere thanks to their participation in the projects. This interest was strongly visible in the focus of the studies themselves; they were almost always concerned first and foremost with human fates, motivations and attitudes and the needs or imperatives that compel people to work and act together. Some projects aimed to discover new exciting realities, such as the work of orchestra conductors (Pazura and Żelazko 2012), but the majority concentrated on everyday settings and places that we all encounter on our way to work, such as riding the bus (Byrska and Kruk 2013), or when shopping, such as at a bazaar (Gurgul et al. 2013). What was remarkable is 
that in most cases, they revealed something unique and compelling in these seemingly mundane settings, where the attraction lay in the social sphere. This was achieved by the use of empathy and of what Czarniawska-Joerges (1992) labels the anthropological frame of mind: an attitude, not the application of a method, characteristic of someone exploring the social domain by adopting an ethnographic sensibility. This attitude encompasses an openness to new realities and meanings and a constant need to problematise, as well as a reluctance to take anything for granted, in a similar spirit of what Wright has suggested mobilised the first organisational ethnographers such as Warner: "The researcher may start with a general issue, but the gold nugget of a 'problem' is only found after fieldwork has begun and it emerges from this process of holding field data up to current academic understandings" (Wright 2013, 102). At its heart lies a constant sense of inquisitiveness and the ability to be amazed by the world. Therefore, even in everyday surroundings, the organisational researcher with an ethnographic approach looks at it with curious eyes; it is an intellectual challenge.

In Evan Willis' (1993) framework, the students learned sociological imagination in four interrelated ways: historical, cultural, structural and critical. Historical factors concern the effect of the past on the present. In most projects, the past of the studied organisations, settings, professions, and social actors themselves featured prominently. The interviewees were usually explicitly asked about their history with the field, and quite regularly, they also commented on the broader historical context. For example, the orchestra conductors (Pazura and Żelazko 2012) recalled their own progression within the profession, their education and work with different orchestras, and some volunteered to add a more general history of their profession in Poland, probably extending beyond their own lifetimes. Cultural factors refer to how everyday life is influenced by traditions, values and beliefs, and these were regularly and extensively presented 
by most of the students. Most of the cultural factors were based on interviews in which the interlocutors were asked about their beliefs and traditions that they regarded as important for their work life. Observational material was also sometimes used to provide a cultural understanding. For example, the bazaar (Gurgul et al. 2013) was shown as a traditional Warsaw marketplace, one of many where the inhabitants used to engage in a large variety of practices and customs, ranging from the buying and selling of products via socialising to engaging with Warsaw folklore, which was abundant in such places. Structural factors concern how social structure and institutions affect how people live and organise. Some, if not most, of the projects addressed structural issues, showing how being a member of a certain class or group equipped the actors with certain advantages, disadvantages or constraints. For example, the study of the fringe political group (Duda et al. 2013) presented the disadvantaged social situation of the participants, their poverty and isolation, and their lack of adequate political representation on any level of the democratic institutions. Finally, critical factors touch on the following questions: Why are things the way they are? How can social actors improve their situations? As with structural factors, a minority, albeit a significant minority, of the projects, addressed these aspects of the studied fields. The interviewees sometimes reflected on such issues themselves, and sometimes, they were accompanied in the reflections by the researchers. For example, the study of the police (Siewczyk and Skoneczna 2009) contained a significant amount of material of this kind, mostly due to the outstanding reflexivity of one of the interviewees, a police officer but also to the openness of the students and their willingness to participate in a critical conversation with him. The study revealed that local police stations in Poland are often ill equipped and lacking in resources, and officers are often simply aggressive or are discouraged from having high ethical standards. Female police officers have a particularly difficult time working in some settings, as the culture is strongly misogynistic. Both the interviewee and the students believed that more 
women in the police force and more respect for them would vastly improve the culture. However, they also believed that a fairer distribution of means and better organisation was needed to really make a difference.

The students gained an understanding of how the social works and what influences it through immersion and empathic sensitivity to the field: the ethnographic and sociologic imagination were recognized in the projects by means of the students' direct experience, in John Van Maanen's words, their "cultural picturing of how it is to be someone else" (1998, xx). An emancipatory potential have been developed by understanding, problematising, practicing and learning. We propose that only by gaining a deeply personal and direct experience of this type was this encounter of these two types of imagination possible, making room for a variety of illuminations and insights, including those concerning the development of organisational imagination or the sensibility to organise to make a connection between theory (reflection) and practice. In quite a number of projects, this imagination featured strongly in terms of a direct understanding of how social context and its different aspects translate into everyday organisational practices. Organising was presented as the realisation of social and individual situations and agendas: more or less taken for granted, depending on the capacity for reflexivity of the actors and researchers. By acquiring a deeper understanding of the everyday life of organisational actors at lower hierarchical levels and belonging to marginalised groups, they gained a critical view at organisational cultures. Such an insight may have helped them to extend the basis for making life choices and, so, may have had an emancipative effect. 


\section{Discussion}

To summarise, organisational ethnography can be seen as a multi-dimension, holistic, and radical learning engagement. As researchers from both anthropology and OS, we can all learn from the students how to engage with ethnography as a way of learning sociological imagination: first and foremost as an engagement and an affirmation of the social. Furthermore, organisational ethnography seen in this manner can be fruitfully employed in both OS and in anthropology, as it was in the early stages of the discipline and unfortunately was separated later by forces unrelated to research except through academic opportunism. Let us briefly recapitulate, restating the initial dichotomy outlined in the paper. Firstly, the focus of our students was not on organisations as such but on organised settings providing room for action on the meso-level (often understood as the level where processes of organising take place) (see Klein and Kozlowski 2000). Secondly, the studies were based on several research methods, a truly interdisciplinary approach, including observation and interview, and the written essay was just one (together with a presentation in class) of the final products of the fieldwork. Thirdly, the projects did not extend for longer than one semester because of the temporal limitations of the course, but several were consequently continued as field projects for masters' projects and other theses. All of these projects were easily expandable in this way (and could be continued as much longer engagements in the field). Many students expressed regrets that they could not continue their research.

This leads us to a further comment: organisational ethnography may be regarded as a methodology, a research tradition in OS derived from anthropology, but it has a much larger potential when it is reclaiming its roots: to become a mode of doing social science on the mesolevel, a commitment to the social that simultaneously allows the researcher to grasp it from the intellectual distance of the sociological imagination (Mills 1959) and to empathise with it from 
the sensuousness of the ethnographic imagination (Atkinson, 1990; Willis 2000). Ethnography helps to examine the "cultural glasses" that we, as humans, always wear and to give insights into what is normally invisible but what is nevertheless close and dear to us. In doing so, it brings about Freirian conscientization, or learning "to perceive social, political, and economic contradictions and to take action against the oppressive elements of reality" (Freire 1970, 17). This is a radical programme and can be undertaken on a zero budget: ethnographers do not use expensive external tools but their own attention, awareness and senses.

Ethnography is neither subjective nor objective. It is interpretive, mediating two worlds through a third (Agar 1986, 19).

Seen this way, ethnography is a regular mode of experiencing that enables a comprehending and radically problematising approach to the allegedly obvious sphere of everyday life in organisations and elsewhere. Indeed, it should be remembered that according to anthropologists, ethnography is and has always been

a family of methods involving direct and sustained social contact with agents and of richly writing up the encounter, respecting, recording, representing at least partly in its own terms the irreducibility of human experience. Ethnography is the disciplined and deliberate witness-cum-recording of human events (Willis and Trondman 2002, 394). To conclude, we propose that the term organisational ethnography is to be used to signify the type of holistic engagement that we present in this article, as it is very well rooted in the common tradition of $O S$ and anthropology. For other uses, such as referring to methods and techniques adopted for qualitative research, we propose the term ethnographic research methods, as more adequate.

This distinction enables a much desired reconnection between research traditions within the social sciences, aiming at a more profound understanding of the social - a task of great importance and urgency in times of interregnum, when new solutions and even institutions are 
vitally needed (Bauman 2012). As Paul Willis and Mats Trondman state in their Manifesto for Ethnography $(2002,395)$, "the best ethnography also recognizes and records how experience is entrained in the flow of contemporary history, large and small, partly caught up in its movement, partly itself creatively helping to maintain it, enacting the uncertainty of the eddies and gathering flows dryly recorded from the outside as 'structures' and 'trends'." Understood and practiced in such a way,

it might provide a usable methodology for investigating constraints and possibilities in social reality, for exploring margins of freedom as the future as well as the past embedded in the present. The crisis of the social sciences need not be an unending crisis. It is possible to regain a critical and dialogical consciousness (Willis and Trondman 2002, 401).

\section{Coda}

Following a suggestion of one of the Reviewers and of the Editor, we would like to conclude this text in a mode that used to be rather popular many years ago, but which nowadays has practically disappeared from academic writing: with our own reflections, in our own words, without citing or referring to other authors. Such an ending is intended as a direct communication aimed at the Reader, a more personal invitation to a dialogue. We are grateful for this suggestion and would like to use this space to reflect on the need to re-imagine education and research into organizations at a time when higher education itself is being subjected to a narrowing and reduction as an idea and as praxis.

In the recent decades, imagination has become something of a taboo, we feel, a topic one should not, especially as a social scientist, engage in. At the same time, there have been numerous attempts to define and even quantify ethnographic methods, forcing them into Procrustean beds of normative and fixed regulations, outer measures and rules of "ethical committees", making it 
near impossible to protect our interviewees' privacy (and so being truly ethical), undertake ethnographic research in certain settings and using some of the classical methods, such as nonparticipant observation. In many places, such as notably British universities, it is close to unrealisable to teach ethnography in the way that has been described in this paper.

We believe that we should stop being apologetic about ethnographic methods and teaching, as long as we follow the intrinsic, profoundly ethical and humanistic rules of ethnography, understood as holistic engagement. We also believe that it is of vital importance that organisation studies go back to developing imagination, by means of research, as well as education, in order to help people to extend their possible worlds, and bring about organising for compassion and for imaginative, radical problem solving, following in the footsteps of the tradition of emancipatory pedagogy. Various contemporary thinkers have been crying out for the urgent need to reclaim imagination, from Zygmunt Bauman, via Tony Watson to David Graeber, and we humbly join this list. We believe that the voices of our students and their beautiful field work speak out for the cause loudly and delightfully. Yes, there is an alternative. And there may be more, if we let those students use the insights they have made and the imagination they have recognised that is theirs, to walk in and to experience. 


\section{References}

Agar, M. 1986. Speaking of Ethnography. Newbury Park: Sage.

Alvesson, M. and S. Deetz 2000 Doing Critical Management Research. Thousand Oaks: SAGE.

Atkinson, P. 1990. The Ethnographic Imagination, London: Routledge.

Baba, M. L. 2009. "W. Lloyd Warner and the Anthropology of Institutions: An Approach to the Study of Work in Late Capitalism." Anthropology of Work Review 30 (2): 29-49.

Banaszak, M., I. Sobczyk, and J. Zakrzewski. 2013. Wyścigi. Class project, Warszawa: University of Warsaw.

Bate, S. P. 1997. "Whatever Happened to Organizational Anthropology? A Review of the Field of Organizational Ethnography and Anthropological Studies." Human Relations 50 (9): 1147-1175.

Bauman, Z. 2012. “Times of Interregnum.” Ethics and Global Politics 5 (1): 49-56.

Bechky, B. 2103. "It's All in the Details: Ethnographies of Organizational Life." Journal of

Organizational Ethnography 2 (1): 92-116.

Bernard, H. R. 2011. Research Methods in Anthropology: Qualitative and Quantitative Approaches. Lanham, Md.: Rowman Altamira.

Bryman, A. and E. Bell. 2007. Business Research Methods. Oxford: Oxford University Press.

Byrska, M. and A. Kruk. 2013. Kierowca autobusu. Class project, Warszawa: University of Warsaw.

Cała, Ł., A. Kłos, E. Kruk, and M. Wąsowski. 2008. Klub Opium. Class project, Warszawa: University of Warsaw.

Collis, J. and R. Hussey. 2003. Business Research: A Practical Guide for Undergraduate and Postgraduate Students. London: Palgrave MacMillan.

Charriere, S. and F. Durieux. 2001. "Exploring and Testing." In Doing Management Research: $A$ comprehensive guide, edited by R-A Thietart, London: Sage.

Cunliffe, A. 2004. "On Becoming a Critically Reflexive Practitioner." Journal of Management Education 28 (4): 407-426.

Czarniawska, B. 2004. Narratives in Social Science Research. London: Sage.

Czarniawska, B. 2008. A Theory of Organizing. London: Sage.

Czarniawska, B. 2014. Social Science Research: From Field to Desk. Los Angeles: Sage.

Czarniawska-Joerges, B. 1992. Exploring Complex Organizations: A Cultural Perspective. Newbury Park: Sage.

Czarniawska-Joerges, B. 1993. The Narrative Approach to Organisation Studies. Lund: School of Economics and Management. 
Dahles, H., H. Höpfl, and J. Koning. 2014. Organizational Ethnography: The Theoretical Challenge. Rotterdam: EGOS 2014 Conference. Sub-theme 15 Call for papers.

Davis, G. F., and C. Marquis. 2005. "Prospects for Organization Theory in the Early Twenty-first Century: Institutional Fields and Mechanisms." Organization Science 16 (4): 332-43.

Down, S. 2001. "The Use of History in Business and Management, and Some Implications for Management Learning." Management Learning 32 (3): 393-415.

Down, S. 2012. "A Historiographical Account of Workplace and Organizational Ethnography." Journal of Organizational Ethnography 1 (1): 72-82.

Duda, D., M. Łebkowski, and K. Wojtkowska. 2013. Solidarni. Class project, Warszawa: University of Warsaw.

Easterby-Smith, M., R. Thorpe, and A. Lowe. 2002. Management Research: An Introduction. London: Sage.

Erlingsdóttir, G. 1999. Förförande idéer: Kvalitetssäkring i hälso- och sjukvården. Lund: Lund University Press.

Evans-Pritchard, E . 1937. Witchcraft, Oracles and Magic among the Azande. Oxford: Oxford University Press.

Evans-Pritchard, E. 1940. The Nuer: A Description of the Modes of Livelihood and Political Institutions of a Nilotic People. Oxford: Clarendon Press.

Evans-Pritchard, E. 1949. The Sanusi of Cyrenaica. London-Oxford: Oxford University Press.

Evans-Pritchard, E .1951. "Kinship and Local Community among the Nuer." In African Systems of Kinship and Marriage, edited by A.R. Radcliffe-Brown, 360-391, London: Oxford University Press.

Fineman, S. 2013. Professor Steven Fineman Profile. http://www.bath.ac.uk/management/faculty/steve fineman.html. Accessed 18/11/2013.

Freire, P. 1970 Pedagogy of the oppressed. New York: Continuum Books.

Freire, P. 1974. Education for Critical Consciousness. New York: Continuum International Publishing Group.

Gaggiotti, H. 2011. Field Notes from Meetings with Organizational Ethnographers at the Standing Conference of Organizational Ethnography. Barcelona: EAE Business School.

Gellner, D. N., and E. Hirsch, eds. 2001. Inside Organizations: Anthropologists at Work. Oxford: Berg.

Ghorashi, H. And H. Wels 2009. "Beyong Complicity: A Pleas for Engaged Ethnography”, In: Organizational Ethnography: Studying the Complexities of Everyday Life edited by S. Ybema, D. Yanow, H. Wels and F. H. Kamsteeg, 231-253. London: Sage.

Gill J., and P. Johnson 2002. Research Methods for Managers. London: Sage.

Gillespie, R. 1993. Manufacturing Knowledge: A History of the Hawthorne Experiments. Cambridge: Cambridge University Press. 
Giroux, H.A., and McLaren, P. 1989. Critical pedagogy, the state, and cultural struggle. New York: SUNY Press.

Gurgul, K., B. Gutowska, and A. Piątkowski. 2013. Bazar Różyckiego. Class project, Warszawa: University of Warsaw.

Ho, K. 2009. Liquidated: An Ethnography of Wall Street. Durham and London: Duke University Press.

Hodson, R. 2004. "A Meta-Analysis of Workplace Ethnographies: Race, Gender, and Employee Attitudes and Behaviors.” Journal of Contemporary Ethnography 33 (1): 4-38.

Ingold, T. 2008. “Anthropology is Not Ethnography. ” Proceedings of the British Academy 154: 69-92.

Jacques, R. S. 2006. "History, Historiography and Organization Studies: The Challenge and the Potential." Management \& Organizational History 1 (1): 31-49.

Jewasińska, M., E. Jurkiewicz, and M. Muras. 2012. The Restaurant as Seen from the Kitchen. Class project, Warszawa: University of Warsaw.

Jordan, A. 2003. Business Anthropology. Long Grove: Waveland Press.

Karpiuk, M., Kotlarz, K., Martynia, M. and Pieniowska, J. 2013. Studenckie koło astronautyczne. Class project, Warszawa: University of Warsaw.

Klein, K., S. Kozlowski, eds. 2000. Multilevel Theory, Research and Methods in Organizations: Foundations, Extensions and New Directions. San Francisco: Jossey-Bass.

Kostera, M. 1996. Postmodernizm w zarzadzaniu. Warszawa: PWE.

Kostera, M. 2007. Organisational Ethnography: Methods and Inspirations. Lund: Studentliteratur.

Kostera, M. 2014. Occupy Management! Inspirations and Ideas for Self-organization and Selfmanagement. London: Routledge.

Krasny, K., M. Łuczaj, S. Sapińska, and A. Walkiewicz. 2013. Gry miejskie. Class project, Warszawa: University of Warsaw.

Kulick D and M. Willson. 1995. Taboo: sex, identity, and erotic subjectivity in anthropological fieldwork. London and New York: Routledge.

Lee, N., and I. Lings. 2008. Doing Business Research. A Guide to Theory and Practice. London: Sage.

Luthans F., et al. 2013. Reflective commentary on 'Anthropology: The Forgotten Behavioral Science in Management History.” Journal of Organizational Ethnography 2 (1): 92-116.

Malinowski, B. 1922. Argonauts of the Western Pacific: An account of native enterprise and adventure in the Archipelagoes of Melanesian New Guinea. London: Routledge and Kegan Paul.

Markowitz F., and M. Ashkenazi. 1999. Sex, Sexuality, and the Anthropologist. Urbana: University of Illinois Press.

Mayo, E. 1933. The Human Problems of an Industrial Civilization. New York: Macmillan. 
McLaren, P. 2003 "Revolutionary pedagogy in post-revolutionary times: Rethinking the political economy of critical education," In The critical pedagogy reader edited by A. Darder, M. Baltodano and R.D. Torres, 151-184. New York: Routledge Falmer.

Mills, C. W. 1959. The Sociological Imagination. London: Oxford University Press.

Mir, R. and A. Mir. 2002. „The Organizational Imagination: From Paradigm Wars to Praxis.” Organizational Research Methods 5 (1): 105-125.

Morey, N., and F. Luthans. 2013[1987]. "Revisiting the Past: Anthropology, the Forgotten Behavioral Science in Management History." Journal of Organizational Ethnography 2 (1): 82-91.

Morgan, G. 1993. Imaginization: New Mindsets for Seeing, Organizing and Managing. Thousand Oaks: Sage.

Nash, D., et al. 1972. "The Emergence of Self-Consciousness in Ethnography [and Comments and Reply]." Current Anthropology 13 (5): 527-42.

Neyland, D. 2008. Organizational Ethnography. London: Sage.

Nouri, A. And S.M. Sajjadi 2014 "Emancipatory Pedagogy in Practice: Aims, Principles and Curriculum Orientation”, International Journal of Critical Pedagogy 5(2): 76-87.

Pazura, D. and Żelazko, M. 2012. Dyrygenci. Class project, Warszawa: University of Warsaw.

Powdermaker H. 1967. Stranger and Friend: The Way of an Anthropologist. New York: W. W. Norton \& Company.

Radcliffe-Brown, A. R. 1931. Social Organization of Australian Tribes. Melbourne: MacMillan.

Rosen, M. 1991. "Coming to Terms with the Field: Understanding and Doing Organizational Ethnography." Journal of Management Studies 28 (1): 1-24.

Royer, I. and P. Zarlowski. 2001. "Research Design.” In Doing Management Research: A comprehensive guide, edited by R-A Thietart, 111-131, London: Sage.

Saunders, M., P. Lewis, and A. Thornhill. 2007. Research Methods for Business Students. London: Prentice-Hall.

Steward, J. 1955. Theory of Culture Change: The Methodology of Multilinear Evolution. Urbana Champaign: University of Illinois Press.

Schwartzman, H. 1993. Ethnography in Organizations. London: Sage.

Siewczyk, A. and A. Skoneczna. 2009. Policjanci. Class project, Warszawa: University of Warsaw.

Sykes, C. S. and Treleaven, L. 2009 "Critical Action Research and Organizational Ethnography" In Organizational Ethnography: Studying the Complexities of Everyday Life edited by S. Ybema, D. Yanow, H. Wels and F. H. Kamsteeg, 215-230. London: Sage.

Tota, A. L. 2004. "Ethnographing Public Memory: The Commemorative Genre of the Victims of Terrorism in Italy." Qualitative Research 4 (2): 131-159.

Van Maanen, J. 1988 Tales from the Field: On writing ethnography. Chicago: The Universoty of Chicago Press. 
Van Maanen, J. 1998. "Different Strokes: Qualitative Research in the Administrative Science Quarterly from 1956 to 1996.” In Qualitative Studies of Organizations, edited by J. Van Maanen, ix - xxxii, Thousand Oaks: Sage.

Van Maanen, J. 2011. “Ethnography as Work: Some Rules of Engagement.” Journal of Management Studies 48 (1): 218-234.

Van Maanen, J. 2013. "Hold the Mayo: Some Comments on the Origins of Organizational Ethnography." Journal of Organizational Ethnography 2 (1): 105-107.

Warner, W. L. and J. O. Low. 1947. The Social System of the Modern Factory. The Strike: a Social Analysis. New Haven: Yale University Press.

Watson, T. J. 2001. In Search of Management: Culture, control and chaos in managerial work. London: South-Western Cengage Learning.

Watson, T.J. 2009. "Work and the Sociological Imagination: The need for continuity and change in the study of continuity and change", Sociology, 43/5, p. 861-877.

Watson, T.J. 2011. "Ethnography, Reality and Truth: The vital needs for studies of "how things work' in organizations and management", Journal of Management Studies, 48/1, p. 202216.

Weick, K. E. 2001. Making Sense of Organization. Oxford: Blackwell.

Whyte, W.F. 1948. Human Relations in the Restaurant Industry, New York: McGraw-Hill.

Willis, E. 1993. The Sociological Quest: An Introduction to the Study of Social Life. Sydney: Allen \& Unwin.

Willis, P. 1981. Learning to Labour: How Working Class Kids Get Working Class Jobs. New York: Columbia University Press.

Willis, P. 1999. "Labor Power, Culture, and the Cultural Commodity." In Critical Education in the New Education Age, edited by M. Castells, R. Flecha, P. Freire, H. A. Giroux, D. Macedo, and P. Willis, 139-171. Lanham: Rowman \& Littlefield.

Willis, P. 2000. The Ethnographic Imagination. Cambridge: Polity.

Willis, P. and M. Trondman. 2002. "Manifesto for Ethnography." Cultural Studies $\leftrightarrow$ Critical Methodologies 2 (3), 394-402.

Wolcott, H. F. 1999. Ethnography: A Way of Seeing. Lanham: Rowman Altamira.

Wright, S. 1994. "Culture in anthropology and organizational studies". In Anthropology of organizations, edited by S. Wright, 1-31, London - New York: Routledge.

Wright, S. 2013. "Forgotten Histories of the Anthropology of Organizations." Journal of Organizational Ethnography 2 (1): 92-116.

Yanow, D. 2009. "Organizational Ethnography and Methodological Angst: Myths and Challenges in the Field." Qualitative Research in Organizations and Management: An International Journal 4 (2): 186-99.

Yanow, D. and K. Geuijen. 2009. “Annotated Bibliography: Defining 'Organizational Ethnography’: Selection Criteria.” In Organizational Ethnography: Studying the 
Complexities of Everyday Life, edited by S. Ybema, D. Yanow, H. Wels, and F. Kamsteeg, 253-259, London: Sage.

Yanow, D., S. Ybema, and M. van Hulst. 2012. "Practicing Organizational Ethnography." In Qualitative Organizational Research: Core Methods and Current Challenge, edited by G. Symon and C. Cassell, 331-350, London: Sage. 